Коломісць Н. $\boldsymbol{C}$.

кандидат філологічних наук, доцент КПІ ДВНЗ «Криворізький національний університет»

\title{
ЕВОЛЮЦІЯ ГЕРОЇЧНОГО ЕПОСУ ЗАХІДНОЇ ЄВРОПИ ДОБИ ПІЗНЬОГО СЕРЕДНЬОВІЧЧЯ
}

У статті розкрито особливості класичного епосу, щьо є витвором усної колективноі та писемно-індивідуальної традиції. Проаналізовано видатні епічні твори пізнього Середньовіччя: «Пісню про Роланда», «Пісню про мого Сіда», «Пісню про нібелунгів». Значну увагу приділено типологічній спільності геройчних поем, створених різними народами Свропи, щзо виявляється на ідейно-тематичному та художньому рівнях; пояснюється рядом історичних явищ.

Ключові слова: Середньовіччя, героїчний епос, поема.

В статье раскрыты особенности классического эпоса, который является творением устной коллективной и письменно-индивидуальной традиции. Проанализировань выдаюшиеся эпические произведения позднего Средневековья: «Песнь о Роланде», «Песнь о моем Сиде», «Песнь о нибелунгах». Значительное внимание уделено типологической общности герочческих поэм, созданных разными народами Европы, что проявляется на идейно-тематическом и художественном уровнях; объясняется рядом исторических явлений.

Ключевые слова: Средневековье, героический эпос, поэма.

In the article the features of classical epic that is the product of a collective oral and in writing-individual tradition. Outstanding epics of the late middle Ages were analyzed, such as: "the Song of Roland», "Song of my Cid», «the Song of the nibelungs». Considerable attention is devoted 
to typological generality of the heroic poems, created by different nations of Europe, which is manifested in the ideological-thematic and artistic levels; due to a number of historical events.

Key words: Medieval, heroic epic, poem.

Актуальність теми статті обумовлена зростаючим інтересом сучасного літературознавства до епосу Середньовіччя як плацдарму для формування національних літератур Західної Європи. В історії світової літератури різнонаціональні культурні надбання традиційно трактуються відокремлено. Тімохін В. В. стверджує, що подібний підхід «... перешкоджає не тільки формуванню уявлення про єдиний літературний процес, але й розумінню своєрідності розвитку самих національних літератур, бо в прочесі становлення вони не тільки входили у своєрідний діалог, в якому не «повторювали думку співрозмовника, а продовжували ї̈», але ц̌ формування всіх літератур в Свропі було взаємопов'язаним $і$ обумовленим. <..> Окремі наукові дослідження останніх десятиліть спрямовані на подолання «традищї» вивчення твору в межах історії одного народу» [Тимохин 2000: 8]. Саме в такому аспекті доцільно розглядати специфіку бачення історичних подій середньовічною людиною, особливості художнього втілення ідеалів, які упродовж попередніх століть визначали першооснови життя.

У сучасному науковому дискурсі літературний процес пізнього Середньовіччя окреслено в різноманітних культурних контекстах. Соціальнокультурний зріз епохи подано в працях А. Я. Гуревича, Т. Б. Рябової, М. С. Шаповалової та ін. Жанрову специфіку творів розглядали О. А. Галич, О. В. Сидоренко, А. В. Скрипник та ін. Особливості естетичних уявлень «героїчної епохи» з'ясовано в дослідженнях М. В. Кордона, Б. Б. Шалагінова та ін. Проведений аналіз дозволяє стверджувати, що у вітчизняній науці проблему розвитку героїчного епосу доби пізнього Середньовіччя на західноєвропейській території грунтовно не вивчено.

Мета статті полягає в тому, щоб з’ясувати еволюцію класичного героїчного епосу на прикладі різнонаціональних поем (французької «Пісня про Роланда», іспанської «Пісня про мого Сіда», німецької «Пісня про нібелунгів»). 
У поемах зрілого Середньовіччя відбито народну точку зору на важливі для національної історії явища, що відбувалися в «епічну» добу. Орієнтація на історію й визначила специфіку класичного героїчного епосу. Події відтворено на конкретному географічному та етнічному тлі. У XI-XIII століттях племінні інтереси поступово нівелювалися, зливаючись із національними, державними. Тому в поемах більшості народів мотив захисту роду трансформувався в тему відстоювання інтересів держави.

Епізод смерті героя (як невід'ємна частина сюжету героїчного епосу) увиразнює тогочасне розуміння суспільної моральної поведінки та соціального ідеалу. У період розпаду патріархально-родових стосунків та зародження феодально-родових міжусобиць епічний герой гине в сутичках із родичами (убивство Зігфріда, загибель Гунтера та його братів у німецькому епосі). За умов сформованої народної самосвідомості він приймає смерть під час бою як захисник своєї країни (смерть Роланда у французькій поемі).

У порівнянні з архаїчним, у класичному епосі дійсність змальовано більш достовірно. Цьому сприяли як зменшення ролі казково-міфологічних деталей, так і розробка суспільно-важливих тем (відданість державі, захист країни від завойовників, вірність королю, засудження феодального розбрату тощо).

Новаторство періоду позначилося й на образній системі творів. «Міфологічні образи (по мірі того, як племінна свідомість у зв'язку з етнополітичною консолідацією підіймалася до державної й нащуіональної) поступово витіснилися історичними» [Мелетинский 1963: 423]. Персонажі часто мали реальних прототипів (Карл Великий, Роланд у французькій літературі; Марко Королевич у сербському або Сід в іспанському епосі та ін.).

У німецькому епосі історичне минуле постає в масштабах героїчної ідеалізації. Його репрезентовано поемами «Гудруна», «Пісня про нібелунгів», циклами поем про Дітріха Бернського, Вольф-Дітріха та ін. У цих творах історичну конкретику естетизовано 3 позиції феодально-лицарської Німеччини. Зі зміною суспільної формації (за умов розпаду родового ладу) шлюб та одруження богатиря не розглядалися як героїчні діяння. Уважалося, що «герой 
епосу часів утворення державного устрою повинен здійснювати подвиг не в інтересах роду, а в інтересах держави» [Пропп 1999: 83]. Концепти роду та племені поступалися поняттям сім’ї та феодальної ієрархії, з’являвся мотив васального обов'язку. Із середини XII століття в епосі німецьких шпільманів традиційний мотив сватання осмислювався відповідно до ціннісних орієнтирів феодальної епохи (наприклад, сватання заморських гостей). Разом із тим, ідея державності та патріотичний пафос не є концептуальними ознаками цих творів.

Змістова складність «Пісні про нібелунгів» полягає в синтезі різнорідних смислових пластів. Колективний автор фольклорних першоджерел поеми трансформує прадавню архетипно-образну основу; автор-інтерпретатор, трактуючи ці тексти, демонструє варіативний суб'єктивізм інформації. Крім того, на власно авторське бачення подій далекого минулого накладається історикосоціальний зміст епохи феодальної Німеччини.

Пласт архаїчних дофеодальних уявлень репрезентовано у творі синтезом героїчних та казкових мотивів: боротьба з драконом, відвойовування скарбів, шлюбні змагання та приборкування нареченої, фантастичні речі (плащневидимка) тощо. У цьому творі важливу роль відіграє мотив «віщого сну», що $\epsilon$ епічним шаблоном для героїчного епосу більшості народів.

Ряд епізодів твору є змістовно близькими до архаїчних епосів, творення яких відбувалося в епоху, коли чудесне видавалося можливим. Прикладом можуть бути картини переправи численного війська в одному човні, масштабний за кількістю учасників (сотні та тисячі воїнів) бій у замку Етцеля, сцена поєдинку між полчищем гунів та двома героями та ін. Сюжет героїчного сватання до Брюнхільди теж має казкові риси. Шлюбний поєдинок між нареченими пов'язаний iз образом богатирської діви, що мав широке розповсюдження в казках i героїчному епосі народів Сходу та Заходу. Як зауважував I. Созонович, у кельтів, германців, тюркських та монгольських народів як у період патріархально-родових стосунків, так і в умовах розвитку феодалізму зберігалися пережитки незалежного становища жінки в сім’і та 
суспільстві. Це виражалося в іiі спочатку рівноправній, а пізніше - епізодичній участі у військових діях [Созонович 1886: 157-164].

«Центральною постаттю іспанського геройчного епосу $є$ Сід, якого народ любовно називав «мій Сід», додаючи - «у добрий час народжений». Це особа історична. Руй (Родріго) Діас де Бівар (близько 1043-1099 рр.) належав до кастільської знаті й був начальником військ у короля Кастілї Санчо ІІ. За військову доблесть він отримав прізвисько Кампеадор (ратоборець, войовник). Маври, які боялися і водночас поважали іспанського полководия, називали його Сідом, щуо по-арабськи означає «пан» <...> Певно, народ щуе за життя Сіда оспівував його подвиги та перемоги. Але з великого епічного матеріалу про Руй Діаса збереглися тільки близька до історичних фактів поема «Пісня про Сіда», поема «Родріго» (ХIV століття), щзо розповідає про молодість героя (у ній значне місие посідає вимисел) та великі циикли романсів XIV-XVI століть» [Рубанова 1982: 76].

В основу сюжету епічної поеми покладено реальні події 3 життя славетного діяча Реконкісти Родріго Діаса де Бівара. Епічного героя твору зображено в різноманітних зв’язках зі світом. Об'єктом зацікавлення автора стали не лише військові перипетії долі Сіда. На відміну від епічного героя французького епосу, його життєве амплуа не обмежене бойовими подвигами. У творі відбито різні аспекти родинного, побутового життя персонажа. Він вдало поєднує власні прагнення 3 громадськими, концентрує в собі активність та відданість меті. Це цільна натура, що вирізняється високим моральним рівнем, почуттям людської гордості та власної гідності. Від Роланда, епічного героя французького епосу, він відрізняється певною поміркованістю. Йому непритаманні гарячність, безрозсудна необачність, пристрасне бажання безкорисного подвигу.

Якщо в «Пісні про Роланда» домінує військова точка зору, то в іспанському епосі картинам баталій та бойових сутичок приділено значно менше уваги. У творі чергуються різномасштабні та різнохарактерні просторові локативи, картини воєнних подій переплітаються з реаліями мирного життя. 
Французький героїчний епос сповнений патріотичного пафосу, у ньому художньо трансформовано народні норми героїчної поведінки, погляд на королівську владу, релігійні уявлення епохи. У пам'ятках осмислено теми захисту країни від зовнішніх ворогів (цикл Гарена де Монглана), служіння королю (Королівський цикл), міжусобних конфліктів (Цикл Доона де Майанса).

У центрі уваги оповідача «Пісні про Роланда» зіткнення християнського Заходу з мавро-мусульманським (сарацинським) Сходом. Особливості конфлікту визначили побудову системи образів. Персонажі поеми поділяються на два антагоністичні табори: захисники інтересів Франції (християни) та іiі вороги (маври), що сповідують іслам. Систему образів вибудувано за принципом контрастної оцінки в залежності від позиції персонажа щодо християнства й лицарської честі. Так, Карл і його прихильники постають хоробрими воїнами, що керуються поняттями доблесті й патріотичного обов'язку. Найяскравішим прикладом може слугувати образ ідеального лицаря Роланда, що є втіленням васальної вірності сюзеренові. Героєві протиставлено Ганелона, який не зміг піднятися над особистими образами, зрадив інтереси свого війська.

«Пісня про Роланда» втілює давнє розуміння героїки, підкресленню якої слугує гіперболізація. Так, двадцять тисяч французів б'ються із чотирьохстами тисячами сарацинів; Карл веде десять полків на тридцять полків маврів; сам Роланд вступає в бій із чотирмастами воїнами тощо.

У творі майже відсутні картини особистого життя персонажів. Вони передусім воїни, державні діячі, яким притаманні вірність сюзерену, наполегливість, сміливість, рішучість, стійкість духу. Почуття васального обов’язку, потреба боротьби у важкий для країни час підносяться в поемі на висоту суспільного ідеалу, громадянського обов’язку. Так, образу Роланда властиві риси епічного героя, зумовлені новими історичними етнокультурними реаліями, які склалися в Свропі після утворення феодальних держав, встановлення суспільних стосунків васала, сеньйора й сюзерена. За словами Роланда, за свого короля слід стерпіти все: і спеку, і мороз. Він знав і виконував усі положення лицарського кодексу, уважав ганебним для себе просити 
допомоги. Богатирське свавілля Роланда стає його трагічною помилкою, причиною поразки й загибелі його та всього ар'єргарду.

На художньому рівні класичному героїчному епосу властива стійка система художніх засобів: сталі епітети, гіперболізація, зачини й кінцівки, триразові повтори, поширені діалоги тощо. Слід відзначити, що «Пісня про нібелунгів» містить цілий ряд архаїчних рис, тоді як «Пісня про мого Сіда» та «Пісня про Роланда» є більш зрілими художніми явищами.

Типологічна спільність героїчних поем, створених різними народами Європи, що виявляється на ідейно-тематичному та художньому рівнях пояснюється рядом історичних явищ. Передусім ці тенденції обумовлені однаковим рівнем історичної свідомості та близькістю етнічної культури країн на етапі формування феодальної епохи. Крім того, схожою була й історична ситуація, що підлягала художньому узагальненню. Засобом же передачі суб'єктивної думки співців послуговувала образна мова, що має спільні корені в європейському фольклорі. Незважаючи на певну типологічну спорідненість героїчного епосу народів Західної Європи, у національних літературах є багато неповторних, специфічних рис.

\section{БІБЛІОГРАФІЯ}

Галич 2003 - Галич О. А. Історія зарубіжної літератури. Античність. Середньовіччя / Галич О. А., Дмитренко В.І., Фоменко В. Г. - Луганськ : Янтар, 2003. $-228 \mathrm{c}$.

Гуревич 2007 - Гуревич А. Я. Избранные труды. Средневековый мир / А. Я. Гуревич. - СПб. : Издательство С.-Петерб. ун-та, 2007. - 560 с.

Мелетинский 1963 - Мелетинский Е. М. Происхождение героического эпоса. Ранние формы и архаические памятники / Е. М. Мелетинский. - М. : Издво восточной литературы, 1963. - 462 с.

Пропп 1999 - Пропп В. Я. Русский героический епос : [собрание трудов] / В. Я. Пропп / [ком. ст. Н. А. Кричниной, сост., науч. ред. С. П. Бушкевич]. - М. : Лабиринт, 1999. - 636 с. 
Рубанова 1982 - Рубанова Г. Л. Історія зарубіжної літератури : Середні віки та Відродження : навчальний посібник / Г. Л. Рубанова, В. А. Моторний. Львів : Вища школа, 1982. - 440 с.

Созонович 1886 - Созонович И. Песни о девушке-воине и былины о Ставре Годиновиче. Варшава, 1886. (Цит. за: Жирмунский В. Эпическое творчество славянских народов и проблемы сравнительного изучения эпоса [Електронний ресурс]: доклад на IV Международном съезде славистов / В. М. Жирмунский - М., 1958. - Режим доступу: http://www.ruthenia.ru/folklore/ zhirmunsky1.htm).

Тимохин 2000 - Тимохин В. В. Поэтика средневекового героического эпоса (повтор, антитеза, тропы) : автореф. дис. на соиск. учен. степ. докт. филол. наук : спец. 10.01.01 «Русская литература», 10.01.05 «Литература народов Западной Европы, Америки и Австралии», 10.01.09 «Фольклористика»/ В. В. Тимохин. - М., 2000. $-57 \mathrm{c}$. 